\title{
Quality and Antioxidant Activity of Yogurt Supplemented with Roselle during Cold Storage
}

\author{
E. L. S. Suharto ${ }^{a}$, I. I. Arief ${ }^{b, *}$, \& E. Taufik ${ }^{b}$ \\ aStudy Program of Animal Production and Technology, Faculty of Animal Science, Graduate School, \\ Bogor Agricultural University \\ ${ }^{b}$ Department of Animal Production and Technology, Faculty of Animal Science, Bogor Agricultural University \\ Jalan Agatis, Kampus IPB Darmaga Bogor 16680, Indonesia \\ (Received 24-11-2015; Reviewed 01-03-2016; Accepted 31-05-2016)
}

\begin{abstract}
The purpose of this study was to determine the quality (physical, chemical, microbiological characteristics), total phenolic content, and antioxidant activity using 1,1-diphenyl-2-picrylhydrazyl radical (DPPH) inhibition assay of probiotic yogurt supplemented with roselle flower extract (Hibiscus sabdariffa $L$ ) during cold storage. The experiment used treatment for types of yogurt as follows: cow's milk probiotic yogurt + roselle, goat's milk probiotic yogurt + roselle, cow's milk yogurt, and goat's milk yogurt. The yogurt was stored in cold storage and evaluated the quality and antioxidant activity variables on days $0,3,6,9,12$, and $15^{\text {th }}$. The results showed that there were interaction $(P<0.05)$ between types of yogurt and storage time on $\mathrm{pH}$ value and total lactic acid bacteria (LAB), but no interaction effect on viscosity. The types of yogurt significantly affected $(P<0.05) a_{w^{\prime}}$ total titrable acid (TTA), total phenolic content, and antioxidant activity. Cow's milk probiotic yogurt + roselle and goat's milk probiotic yogurt + roselle were the best yogurt that contributed to a good quality and high antioxidant activity up to $15 \mathrm{~d}$ at cold storage.
\end{abstract}

Key words: yogurt, roselle, probiotic, antioxidant

\section{ABSTRAK}

Tujuan penelitian ini adalah menentukan kualitas (karakteristik fisik, kimia, mikrobiologi), kandungan total fenolat dan aktivitas antioksidan menggunakan uji hambat 1,1-diphenyl-2-picrylhydrazyl (DPPH) yogurt probiotik dengan penambahan ekstrak bunga rosella (Hibiscus sabdariffa L) selama penyimpanan dingin. Penelitian terdiri atas perlakuan tipe yogurt yaitu yogurt susu kambing, yogurt susu sapi, yogurt susu kambing + Lactobacillus acidophilus IIA-2B4 + rosella, yogurt susu sapi + Lactobacillus acidophilus IIA-2B4 + rosella. Yogurt disimpan pada suhu dingin dan dianalisis kualitas dan peubah aktivitas antioksidannya pada hari ke 0, 3, 6, 9, 12, dan 15. Hasil penelitian menunjukkan bahwa terdapat interaksi yang nyata $(P<0,05)$ antara perlakuan jenis yogurt dan lama penyimpanan terhadap nilai $\mathrm{pH}$ dan total bakteri asam laktat $(\mathrm{BAL})$, tetapi tidak ada pengaruh interaksi terhadap viskositas. Jenis yogurt berpengaruh nyata $(P<0,05)$ terhadap $a_{w^{\prime}}$ total asam tertitrasi $(T A T)$, kandungan total fenolat dan aktivitas antioksidan. Yogurt susu sapi probiotik + rosella dan yogurt susu kambing probiotik + rosella memiliki kualitas fisik, kimia dan mikrobiologi serta nilai aktivitas antioksidan yang paling baik dibandingkan dengan yogurt tanpa pemberian rosella, dan dapat disimpan selama 15 hari pada suhu dingin.

Kata kunci: yogurt, rosella, probiotik, antioksidan

\section{INTRODUCTION}

The development of population welfare that leads to changes in diet has a negative impact on the increase in various kinds of degenerative diseases. Awareness of

${ }^{*}$ Corresponding author:

E-mail: irma_isnafia@yahoo.com the enormity of the relationship between food and the possibility of disease incidence has changed the view that food is not just for filling and as a source of nutrients, but also for health. Health has become increasingly important both personally and socially, due to the costs associated with the medication, thus early prevention of health problems is very important. Most of the health complaints are categorized as a disease that can be pre- 
vented by conducting healthy lifestyle. Physical activity and adequate nutrition are essential aspects in influencing a person's health (Altgeld et al., 2006).

The existence of functional foods offers a good effect on public health. Typical functional food products are enriched with substances such as probiotics, prebiotics or omega-3 fatty acids. Various scientific publications have shown that health is an important motivation to consume functional foods (Szakály et al., 2012).

Milk contains several physiological functional components, including protein, vitamins such as vitamin $\mathrm{E}$ and $C$ as well as carotenoids and flavonoids with antioxidant content. Therefore, milk with high antioxidant capacity can provide potential protection for consumers from the exposure of oxidative stress, that becomes the cause of acute and chronic diseases (Dalle-Donne et al., 2006; Valko et al., 2007). In recent years, there is a significant increase in the popularity of yogurt as a functional food (Granato et al., 2010).

Yogurt is a fermented milk product that rich in nutrients, especially when obtained by fermentation of fresh milk or milk solution with lactic acid bacteria, favored by consumers because of its effect in improving the intestinal environment and boost immunity (Michael et al., 2010). Yogurt is produced by lowering the $\mathrm{pH}$ of the milk protein on isoelectric point $(\mathrm{pH} 4.6)$ through the fermentation of lactose into lactic acid using starter bacteria. Yogurt can be differentiated according to the fat content of milk used in the yogurt production (FAO, 2013).

Previously, two Indonesian probiotics, Lactobacillus plantarum IIA-2C12 and Lactobacillus acidophilus IIA-2B4, were isolated from beef obtained from Indonesian cattle, Peranakan Ongole (Arief et al., 2015a). These bacteria had met the requirements to be classified as probiotic (Arief et al., 2014). In addition, these bacteria also had displayed a remarkable ability to prevent EPEC-causing diarrhea (Arief et al., 2010) and repair the hematology condition of diarrhea suspected rats (Astawan et al., 2011), had functional properties for fermented sausage (Arief et al., 2014; Afiyah et al., 2015) and Lactobacillus plantarum IIA-1A5; another strain; categorized as bacteriocin producer (Arief et al., 2013; Arief et al., 2015b). In this research, indigenous lactic acid bacteria Lactobacillus acidophilus IIA-2B4 was used as probiotic.

The addition of roselle extract can be conducted to improve the quality of the yogurt. Roselle (Hibiscus sabdariffa L.) is a herbal plant that belongs to the family Malvaceae (Cisse et al., 2011). H. sabdariffa contains anthocyanin with high antioxidant activity (El Sherif et al., 2011). Therefore, it is necessary to conduct a study in order to evaluate the quality (physical, chemical and microbiological characteristics) and antioxidant activity of the yogurt.

\section{MATERIALS AND METHODS}

\section{Materials}

The materials used in this study were $6 \mathrm{~L}$ of cow's milk and $6 \mathrm{~L}$ of goat's milk obtained from the milk processing unit "D-Farm" in Bogor Agricultural University, and roselle flower extract. Yogurt cultures used were Lactobacillus delbrueckii subsp bulgaricus RRAM-01, Streptococcus salivarius subsp thermophilus RRAM-01 and Lactobacillus acidophilus IIA-2B4, collections of the Laboratory of Animal Product Technology, Faculty of Animal Science, Bogor Agricultural University, Indonesia.

\section{Subculturing of the Starter}

This was based on bacteria used in the process, namely: yogurt bacteria, Lactobacillus delbrueckii subsp bulgaricus RRAM-01 and Streptococcus salivarius subsp thermophillus RRAM-01. Lactobacillus acidophilus IIA-2B4 was used as probiotic. Starter-subculturing was conducted by inoculating $10 \%$ of yogurt starter into milk that was sterilized in an autoclave at $115^{\circ} \mathrm{C}$ for $3 \mathrm{~min}$. Subsequently, it was incubated at $37^{\circ} \mathrm{C}$ for $18 \mathrm{~h}$ to form coagulation in order to obtain yogurt.

\section{Making of Roselle Flower (Hibiscus sabdariffa L) Extract}

Dried roselle flowers obtained from the grower were finely ground into flour, sieved using a 60-mesh sieve. Roselle flower flour was dissolved in the water at a ratio of $20 \mathrm{~g}$ : $100 \mathrm{~mL}$ and pasteurized at $63-65^{\circ} \mathrm{C}$ for 30 min. The liquid (upper solution) was separated carefully and moved to another bottle for next process (Tsai et al., 2008).

\section{Making of Probiotic Yogurt with the Addition of Roselle Flower}

Goat's milk or cow's milk was heated at $85-90^{\circ} \mathrm{C}$ for 35 minutes, then cooled until the temperature reached $40-45^{\circ} \mathrm{C}$. Yogurt starter (Lactobacillus delbrueckii subsp bulgaricus RRAM-01 and Streptococcus salivarius subsp thermophilus RRAM-01 and Lactobacillus acidophilus IIA-2B4 as probiotic were added to goat's milk or cow's milk. The population used was more than $10^{7} \mathrm{CFU} / \mathrm{mL}$, incubated at $37^{\circ} \mathrm{C}$ for $16 \mathrm{~h}$ to form coagulation (plain yogurt). Then, it was added with $1 \%$ of roselle extract. Yogurt was stored at cold temperatures $\left( \pm 4^{\circ} \mathrm{C}\right)$ with a different storage duration (Donkor et al., 2006).

\section{Analysis of Yogurt Quality}

TTA Value (Total Titratable Acid). Measurement of Total Titratable Acid (TTA) in samples was conducted to measure the amount of organic acids contained in samples. Yogurt sample as much as $10 \mathrm{~mL}$ was added with 3 drops of Phenolphthalein (PP) as an indicator, then the mixture was titrated using $\mathrm{NaOH}$ solution $(0.1 \mathrm{~N})$ to form a pink color that did not disappear when homogenized. The total value of titratable acid was calculated by converting it to lactic acid percentage (AOAC, 2005).

pH Value. $\mathrm{pH}$ measurement was conducted using a $\mathrm{pH}$ meter (Schoot Instrument, SI Analytics GmbH, Mainz Deutschland). PH meter was calibrated with buffer solution at $\mathrm{pH} 4$ and $\mathrm{pH} 7$. The electrode was dipped into a 10 
mL sample, then this number was recorded as a specific $\mathrm{pH}$ value (AOAC, 2005).

Viscosity. The measurement of viscosity was conducted using a rotational viscotester (RION, Tokyo Japan). 100 $\mathrm{ml}$ of sample was loaded into the test cell. The rotor was dipped into the sample and allowed to spin until the needle scale pointer stopped at a certain scale. This scale indicates the viscosity of the sample with dPa.s as the viscosity unit (AOAC, 2005).

Water activity $\left(a_{w}\right), a_{w}$ measurement was conducted using calibrated $a_{w}$ meter (Novasina AG, Lachen Switzerland) $a_{w}$ meter calibration was conducted using saturated $\mathrm{NaCl}$ that has an $\mathrm{a}_{\mathrm{w}}$ value of 0.75 and $\mathrm{BaCl}_{2}$ at $\mathrm{a}_{\mathrm{w}}$ of 0.90 . The sample was introduced into the container/ chamber on $\mathrm{a}_{\mathrm{w}}$ meter, then closed and waited for a few minutes until the $a_{w}$ value of the sample was analyzed (AOAC, 2005).

Total lactic acid bacteria. Amount of $5 \mathrm{~mL}$ of sample was added to the Erlenmeyer flask containing $45 \mathrm{~mL}$ of BPW (Buffer pepton water) solution in order to obtain one-tenth dilution $\left(10^{-1}\right)$. Furthermore, from $10^{-1}$ dilution, $1 \mathrm{~mL}$ was pippeted to be dissolved into a $9 \mathrm{~mL} \mathrm{BPW} \mathrm{dilu-}$ tion solution to obtain $10^{-2}$, and continued until $10^{-8} .1 \mathrm{~mL}$ of sample from $10^{-6}$ to $10^{-8}$ dilutions were inoculated into petri dishes and poured with MRS agar media, shaken thoroughly and then incubated at $37^{\circ} \mathrm{C}$ for $48 \mathrm{~h}$ (AOAC, 2005).

Yogurt extraction. Yogurt with- or without the addition of roselle extract was homogenized with $2.5 \mathrm{~mL}$ of sterile distilled water. Yogurt was then heated with a water bath $\left(45^{\circ} \mathrm{C}\right)$ for $10 \mathrm{~min}$ and centrifuged $(10,000 \mathrm{rpm}, 10 \mathrm{~min}$ at $\left.4^{\circ} \mathrm{C}\right)$. The supernatant was obtained and $\mathrm{NaOH}(0.5$ $\mathrm{M})$ was added until the $\mathrm{pH}$ reached 7.0. The supernatant was centrifuged again $\left(10,000 \mathrm{rpm}, 10 \mathrm{~min}\right.$ at $\left.4^{\circ} \mathrm{C}\right)$, then the precipitate formed was separated and the supernatant obtained was stored at refrigerator temperature until needed for analysis (Shori et al., 2014).

Total phenolic content. Total plenolic content analysis was conducted using Shetty et al. (2005) method. $1 \mathrm{~mL}$ of yogurt extract was transferred into a tube and mixed with $1 \mathrm{~mL}$ of $95 \%$ ethanol and $5 \mathrm{~mL}$ of $\mathrm{dH}_{2} \mathrm{O}$. FolinCiocalteu reagent $(50 \% \mathrm{v} / \mathrm{v} ; 0.5 \mathrm{~mL})$ was added to each sample, then homogenized with a vortex. After $5 \mathrm{~min}, 1$ $\mathrm{mL}$ of $5 \% \mathrm{Na}_{2} \mathrm{CO}_{3}$ was added and allowed to stand for 60 min at room temperature. Absorbance was measured at $725 \mathrm{~nm}$. Absorbance values were converted to total phenol and expressed in micrograms of gallic acid equivalent per mililitre $(\mathrm{mL})$ of sample.

Antioxidant activity using radical 1,1-diphenyl-2-picryl hydrazyl (DPPH) inhibition test. Yogurt extract $(250 \mu \mathrm{L})$ was added to $3 \mathrm{~mL}$ of $60 \mu \mathrm{M}$ DPPH in ethanol. The decrease in absorbance was observed at $517 \mathrm{~nm}$ until constant readings. The readings were compared to control containing $250 \mu \mathrm{L}$ of $\mathrm{dH}_{2} \mathrm{O}$ as the extract replacement (Apostolidis et al., 2006).

\section{Statistical Analysis}

The experiment was carried out in three different batches of yogurt $(n=3)$. Data were expressed as mean \pm deviation standard). Randomized block design with factorial $4 \times 6$ was used in this research. The first factor was type of yogurt (YSSPR= cow's milk probiotic yogurt + roselle, YSKPR= goat's milk probiotic yogurt + roselle, YSS= cow's milk yogurt, YSK= goat's milk yogurt). The second factor was duration of cold storage $(0,3,6,9,12$, and $15 \mathrm{~d}$ ). The statistical analysis was performed using one way analysis of variance (ANOVA), followed by Tukey test (Steel \& Torrie, 1995).

\section{RESULTS}

\section{Viscosity}

The type of yogurt and storage duration significantly $(\mathrm{P}<0.05)$ affected the viscosity of yogurt, but did not interact each other. The observation of viscosity is presented in Table 1. Viscosity describes the consistency of a foodstuff. Table 1 shows the average viscosity of goat's milk probiotic yogurt+roselle stored at refrigerator temperature $\left(4^{\circ} \mathrm{C}\right)$ (Table 1$)$ that demonstrated the highest score at $3.51 \pm 1.60 \mathrm{dPa} . \mathrm{s}$, while the lowest average viscosity was showed by cow's milk yogurt at $1.96 \pm 0.65$ dPa.s. Goat milk had higher total solid and higher fat content than cow's milk, so that the viscosity of goat's milk yogurt was higher than cow's milk.

\section{Water Activity $\left(a_{w}\right)$}

The type of yogurt significantly $(\mathrm{P}<0.05)$ affected the $\mathrm{a}_{\mathrm{w}}$, but the storage duration and the interaction between them did not significantly affect the $a_{w}$. $a_{w}$ values in yogurt ranged from 0.85-0.86 (Table 2).

In the cow's milk probiotic yogurt with the addition of roselle extract, $a_{w}$ value decreased on day- 6 of storage and increased on day- 9 of storage, then $a_{w}$ value decreased again on the day-12 of storage and increased on day-15 of storage, whereas in the cow's milk yogurt $a_{w}$ values on day-0 to day-9 of storages were relatively similar, then decreased on day-12 of storage. In goat's milk probiotic yogurt with the addition of roselle extract, $a_{w}$ value decreased on the day- 6 of storage and increased again on the day-12 of storage, then dropped on the day-15 of storage. In goat's milk yogurt, $a_{w}$ value decreased on the day- 3 of storage and the $a_{w}$ values were relatively similar until the day- 9 of storage and finally decreased again on the day-15 of storage. Water activities were affected complex chemical reaction by many factors such as $\mathrm{pH}$ value, viscosity and texture of the product.

\section{pH Value}

The $\mathrm{pH}$ value is affected by many factors such as products from lactic acid bacteria metabolism, addition of flavor, colorings and other food additives. Table 3 shows the decrease in the $\mathrm{pH}$ value of the four types of yogurt. 
Table 1. Viscosity of yogurt during cold storage temperatures (dPa.s)

\begin{tabular}{cccccc}
\hline \multirow{2}{*}{$\begin{array}{c}\text { Storage duration } \\
\text { (Days on-) }\end{array}$} & \multicolumn{4}{c}{ Type of yogurt } & \multirow{2}{*}{ Average } \\
\cline { 2 - 5 } & YSSPR & YSS & YSKPR & YSK & $1.99 \pm 0.96^{\mathrm{d}}$ \\
3 & $1.90 \pm 0.35$ & $1.27 \pm 0.55$ & $2.43 \pm 1.50$ & $2.37 \pm 1.03$ & $2.38 \pm 1.11^{\mathrm{cd}}$ \\
6 & $2.20 \pm 0.50$ & $1.70 \pm 0.53$ & $2.93 \pm 1.96$ & $2.67 \pm 1.03$ & $2.65 \pm 1.15^{\mathrm{bcd}}$ \\
9 & $2.33 \pm 0.50$ & $1.90 \pm 0.62$ & $3.30 \pm 1.85$ & $3.07 \pm 1.12$ & $2.95 \pm 1.13^{\mathrm{abc}}$ \\
12 & $2.57 \pm 0.42$ & $2.07 \pm 0.57$ & $3.77 \pm 1.66$ & $3.40 \pm 1.01$ & $3.25 \pm 1.18^{\mathrm{ab}}$ \\
15 & $2.77 \pm 0.42$ & $2.27 \pm 0.57$ & $4.13 \pm 1.72$ & $3.83 \pm 0.85$ & $3.58 \pm 1.15^{\mathrm{a}}$ \\
Average & $3.07 \pm 0.45$ & $2.53 \pm 0.67$ & $4.47 \pm 1.48$ & $4.27 \pm 0.74$ & \\
\hline
\end{tabular}

Note: Mean in the same row or column with different superscripts differ significantly $(\mathrm{P}<0.05)$; YSSPR= cow's milk probiotic yogurt + roselle; YSKPR= goat's milk probiotic yogurt + roselle; YSS= cow's milk yogurt; YSK= goat's milk yogurt.

Table 2. $\mathrm{A}_{\mathrm{w}}$ value of yogurt during cold storage temperatures

\begin{tabular}{cccccc}
\hline \multirow{2}{*}{$\begin{array}{c}\text { Storage duration } \\
\text { (Days on-) }\end{array}$} & \multicolumn{4}{c}{ Type of yogurt } & \multirow{2}{*}{ Average } \\
\cline { 2 - 5 } & YSSPR & YSS & YSKPR & YSK & $0.85 \pm 0.01$ \\
3 & $0.86 \pm 0.01$ & $0.86 \pm 0.00$ & $0.85 \pm 0.01$ & $0.86 \pm 0.01$ & $0.86 \pm 0.01$ \\
6 & $0.86 \pm 0.01$ & $0.86 \pm 0.01$ & $0.85 \pm 0.01$ & $0.85 \pm 0.02$ & $0.85 \pm 0.02$ \\
9 & $0.85 \pm 0.01$ & $0.86 \pm 0.00$ & $0.84 \pm 0.01$ & $0.85 \pm 0.03$ & $0.85 \pm 0.02$ \\
12 & $0.87 \pm 0.00$ & $0.86 \pm 0.01$ & $0.84 \pm 0.01$ & $0.85 \pm 0.02$ & $0.85 \pm 0.01$ \\
15 & $0.85 \pm 0.00$ & $0.85 \pm 0.02$ & $0.85 \pm 0.02$ & $0.87 \pm 0.01$ & $0.85 \pm 0.01$ \\
Average & $0.86 \pm 0.01$ & $0.85 \pm 0.01$ & $0.84 \pm 0.01$ & $0.84 \pm 0.01$ & \\
\hline
\end{tabular}

Note: Mean in the same row with different superscripts differ significantly $(\mathrm{P}<0.05)$; YSSPR= cow's milk probiotic yogurt + roselle; $Y$ YSKPR= goat's milk probiotic yogurt + roselle; YSS= cow's milk yogurt; YSK= goat's milk yogurt.

Table 3. $\mathrm{pH}$ value of yogurt during cold storage temperatures

\begin{tabular}{ccccc}
\hline \multirow{2}{*}{$\begin{array}{c}\text { Storage } \\
\text { duration } \\
\text { (Days on-) }\end{array}$} & \multicolumn{4}{c}{ Type of yogurt } \\
\cline { 2 - 5 } & YSSPR & YSS & YSKPR & YSK \\
\hline 0 & $3.72 \pm 0.03^{\mathrm{f}}$ & $4.64 \pm 0.07^{\mathrm{a}}$ & $3.51 \pm 0.01^{\mathrm{f}}$ & $4.50 \pm 0.11^{\mathrm{ab}}$ \\
3 & $3.71 \pm 0.09^{\mathrm{f}}$ & $4.46 \pm 0.10^{\mathrm{ab}}$ & $3.52 \pm 0.03^{\mathrm{f}}$ & $4.28 \pm 0.07^{\mathrm{bc}}$ \\
6 & $3.73 \pm 0.05^{\mathrm{f}}$ & $4.39 \pm 0.12^{\mathrm{abc}}$ & $3.52 \pm 0.01^{\mathrm{f}}$ & $4.21 \pm 0.09^{\mathrm{cd}}$ \\
9 & $3.71 \pm 0.08^{\mathrm{f}}$ & $4.32 \pm 0.15^{\mathrm{bc}}$ & $3.52 \pm 0.05^{\mathrm{f}}$ & $4.19 \pm 0.13^{\mathrm{cd}}$ \\
12 & $3.74 \pm 0.07^{\mathrm{ef}}$ & $4.29 \pm 0.16^{\mathrm{bc}}$ & $3.53 \pm 0.04^{\mathrm{f}}$ & $4.17 \pm 0.13^{\mathrm{cd}}$ \\
15 & $3.69 \pm 0.04^{\mathrm{f}}$ & $4.17 \pm 0.21^{\mathrm{cd}}$ & $3.52 \pm 0.03^{\mathrm{f}}$ & $3.98 \pm 0.09^{\mathrm{de}}$ \\
\hline
\end{tabular}

Note: Mean in the same row or column with different superscripts differ significantly $(\mathrm{P}<0.05)$; YSSPR= cow's milk probiotic yogurt + roselle; YSKPR= goat's milk probiotic yogurt + roselle; YSS= cow's milk yogurt; $\mathrm{YSK}=$ goat's milk yogurt.

The $\mathrm{pH}$ value of yogurts added by roselle was lower than yogurt without roselle. The type of yogurt, storage duration, and the interaction between them significantly $(\mathrm{P}<0.05)$ affected the $\mathrm{pH}$ value of yogurt. The $\mathrm{pH}$ values obtained were in the range of 3.51-4.64. This result was relevant with the elevation of the titratable acidity value of yogurt that was counted as total lactic acid, and acids from roselle addition. This reduction of $\mathrm{pH}$ value enhanced the sour and unique flavor of yogurt during storage (Paseephol et al., 2009; Astawan et al., 2012).

\section{Total Titratable Acid (TTA)}

The type of yogurt was significantly $(\mathrm{P}<0.05)$ affected total titratable acid (TTA) in yogurt (Table 4), but the storage duration and the interaction between them were not significantly $(\mathrm{P}>0.05)$ affecting total titratable acid (TTA) in yogurt. The total titratable acid obtained ranged from $0.92 \%-2.08 \%$. TTA values of 4 types of yogurt during storage still met the Indonesian National Standard (INS) of Yogurt Quality (BSN, 2009).

\section{Total Lactic Acid Bacteria (LAB)}

The total population of lactic acid bacteria in a yogurt product becomes an indicator of microbiological quality of the product. The type of yogurt, storage duration and the interaction between them significantly $(\mathrm{P}<0.05)$ affected the total LAB (Table 5).

\section{Total Phenolic Content}

The result of this study showed that total phenolic content of four types of yogurt with different storage duration ranged between 28.17-64.37 $\mu$ g GAE/mL. Type of yogurt significantly $(\mathrm{P}<0.05)$ affected total phenolic content (Table 6), but the storage duration and the interaction between them did not significantly $(P>0.05)$ affect total phenolic content. 
Table 4. Total titratable acid (TAT) value of yogurt during cold storage temperatures (\%)

\begin{tabular}{cccccc}
\hline \multirow{2}{*}{$\begin{array}{c}\text { Storage duration } \\
\text { (Days on-) }\end{array}$} & \multicolumn{5}{c}{ Type of yogurt } \\
\cline { 2 - 5 } YSSPR & YSS & YSKPR & YSK & $1.39 \pm 0.54$ \\
\hline 0 & $1.59 \pm 0.13$ & $0.81 \pm 0.12$ & $2.09 \pm 0.28$ & $1.09 \pm 0.15$ & $1.43 \pm 0.51$ \\
3 & $1.58 \pm 0.15$ & $0.87 \pm 0.10$ & $2.09 \pm 0.37$ & $1.16 \pm 0.09$ & $1.45 \pm 0.49$ \\
6 & $1.60 \pm 0.13$ & $0.90 \pm 0.10$ & $2.09 \pm 0.31$ & $1.21 \pm 0.07$ & $1.45 \pm 0.47$ \\
9 & $1.59 \pm 0.13$ & $0.91 \pm 0.10$ & $2.06 \pm 0.31$ & $1.24 \pm 0.11$ & $1.46 \pm 0.47$ \\
12 & $1.59 \pm 0.13$ & $0.92 \pm 0.09$ & $2.06 \pm 0.36$ & $1.28 \pm 0.02$ & $1.59 \pm 0.45$ \\
15 & $1.58 \pm 0.14$ & $1.11 \pm 0.32$ & $2.10 \pm 0.36$ & $1.56 \pm 0.33$ & \\
\hline
\end{tabular}

Note: Mean in the same row with different superscripts differ significantly $(\mathrm{P}<0.05)$; YSSPR $=$ cow's milk probiotic yogurt + roselle; $Y S K P R=$ goat's milk probiotic yogurt + roselle; YSS= cow's milk yogurt; YSK= goat's milk yogurt.

Table 5. Total lactic acid bacteria (LAB) of yogurt during cold storage temperatures $(\log \mathrm{cfu} / \mathrm{mL})$

\begin{tabular}{ccccc}
\hline \multirow{2}{*}{$\begin{array}{c}\text { Storage } \\
\text { duration } \\
\text { (Days on-) }\end{array}$} & \multicolumn{4}{c}{ YSSPR of yogurt } \\
\cline { 2 - 5 } & YSS & YSKPR & YSK \\
\hline 0 & $9.02 \pm 0.19^{\mathrm{a}}$ & $9.43 \pm 0.13^{\mathrm{a}}$ & $8.67 \pm 0.29^{\mathrm{a}}$ & $9.49 \pm 0.01^{\mathrm{a}}$ \\
3 & $8.77 \pm 0.19^{\mathrm{a}}$ & $9.43 \pm 0.08^{\mathrm{a}}$ & $8.32 \pm 0.45^{\mathrm{a}}$ & $9.44 \pm 0.09^{\mathrm{a}}$ \\
6 & $8.72 \pm 0.45^{\mathrm{a}}$ & $9.41 \pm 0.14^{\mathrm{a}}$ & $7.86 \pm 0.61^{\mathrm{ab}}$ & $9.38 \pm 0.08^{\mathrm{a}}$ \\
9 & $8.55 \pm 0.39^{\mathrm{a}}$ & $9.39 \pm 0.06^{\mathrm{a}}$ & $6.43 \pm 1.28^{\mathrm{bc}}$ & $9.33 \pm 0.22^{\mathrm{a}}$ \\
12 & $8.53 \pm 0.06^{\mathrm{a}}$ & $9.33 \pm 0.05^{\mathrm{a}}$ & $6.40 \pm 1.43^{\mathrm{bc}}$ & $9.33 \pm 0.12^{\mathrm{a}}$ \\
15 & $8.33 \pm 0.44^{\mathrm{a}}$ & $9.20 \pm 0.55^{\mathrm{a}}$ & $6.02 \pm 1.37^{\mathrm{c}}$ & $9.25 \pm 0.34^{\mathrm{a}}$ \\
\hline
\end{tabular}

Note: Mean in the same row or column with different superscripts differ significantly $(\mathrm{P}<0.05)$; YSSPR $=$ cow's $^{\prime}$ milk probiotic yogurt + roselle; $\mathrm{YSKPR}=$ goat's milk probiotic yogurt + roselle; YSS= cow's milk yogurt; $\mathrm{YSK}=$ goat's milk yogurt.

\section{Antioxidant Activity Value (DPPH)}

The results showed that the lowest antioxidant activity was shown by goat's milk yogurt, while the highest antioxidant activity produced by goat's milk probiotic yogurt with the addition of roselle extract. Results of analysis of variance showed that the type of yogurt significantly $(\mathrm{P}<0.05)$ affected the antioxidant activity (Table 7), but the storage duration and the interaction between them did not significantly $(\mathrm{P}>0.05)$ affect the antioxidant activity. According to the $\mathrm{IC}_{50}$ calculation, four types of yogurt have the $\mathrm{IC}_{50}$ between 9.63-15.06 ppm and $\mathrm{IC}_{50}$ value of vitamin $\mathrm{C}$ of 15.07 ppm (Table 8).

\section{DISCUSSION}

The effect of storage duration treatment in the refrigerator temperature at $4^{\circ} \mathrm{C}$ on the viscosity of yogurt was progressively increasing. This is due to the influence of the low temperature in the refrigerator, causing clots in the yogurt. According to Astawan et al. (2012), the cooling and the storage process after fermentation increased viscosity caused by protein hydration and compaction of yogurt gel structure. The changes of milk acidity affected protein isoelectric point and changed the protein solubility. In this research, beside affected by the metabolism yield acidity of the starter bacteria that convert lactose into lactic acid, $\mathrm{pH}$ value was also affected by roselle addition. The activity of microorganisms converted milk lactose into lactic acid followed by lowering $\mathrm{pH}$. The decrease in $\mathrm{pH}$ depends on the activity and amount of LAB in producing lactic acid. Not only lactic acid bacteria, but also roselle contributed to $\mathrm{pH}$ value of yogurt. Roselle extract has low $\mathrm{pH}$ value as 2.00 with total titratable acid $0.27 \%$.

The total titratable acid in yogurt was inversely proportional to the $\mathrm{pH}$ value. This is due to the higher amount of acid produced that caused the higher decrease in $\mathrm{pH}$. This statement can be proven in Table 4, in which the average total titratable acid in goat's milk

Table 6. Total phenolic content of yogurt during cold storage temperatures ( $\mu \mathrm{g}$ GAE/mL)

\begin{tabular}{|c|c|c|c|c|c|}
\hline \multirow{2}{*}{$\begin{array}{l}\text { Storage duration } \\
\text { (Days on-) }\end{array}$} & \multicolumn{4}{|c|}{ Type of yogurt } & \multirow{2}{*}{ Average } \\
\hline & YSSPR & YSS & YSKPR & YSK & \\
\hline 0 & $51.70 \pm 4.98$ & $31.72 \pm 0.72$ & $63.51 \pm 8.72$ & $25.25 \pm 3.17$ & $43.05 \pm 16.62$ \\
\hline 3 & $50.72 \pm 5.72$ & $34.21 \pm 4.20$ & $65.62 \pm 5.29$ & $27.99 \pm 6.27$ & $44.63 \pm 16.02$ \\
\hline 6 & $55.54 \pm 1.33$ & $43.33 \pm 10.56$ & $61.79 \pm 3.65$ & $27.61 \pm 5.16$ & $47.07 \pm 14.62$ \\
\hline 9 & $55.93 \pm 3.97$ & $37.79 \pm 7.00$ & $63.92 \pm 12.18$ & $28.40 \pm 5.29$ & $44.68 \pm 16.21$ \\
\hline 12 & $51.49 \pm 9.18$ & $34.90 \pm 4.41$ & $58.40 \pm 12.82$ & $29.55 \pm 3.65$ & $45.42 \pm 14.31$ \\
\hline 15 & $54.72 \pm 10.08$ & $35.94 \pm 3.43$ & $72.96 \pm 9.17$ & $30.21 \pm 3.35$ & $48.46 \pm 18.60$ \\
\hline Average & $53.35 \pm 5.95^{b}$ & $36.31 \pm 6.22^{c}$ & $64.37 \pm 9.02^{\mathrm{a}}$ & $28.17 \pm 4.21^{\mathrm{d}}$ & \\
\hline
\end{tabular}

Note: Mean in the same row with different superscripts differ significantly $(\mathrm{P}<0.05)$; YSSPR= cow's milk probiotic yogurt + roselle; $\mathrm{YSKPR}=$ goat's milk probiotic yogurt + roselle; YSS= cow's milk yogurt; YSK= goat's milk yogurt. 
Table 7. Antioxidant activity value of yogurt during cold storage temperatures (\%)

\begin{tabular}{cccccc}
\hline \multirow{2}{*}{$\begin{array}{c}\text { Storage duration } \\
\text { (Days on-) }\end{array}$} & \multicolumn{5}{c}{ Type of yogurt } \\
\cline { 2 - 5 }
\end{tabular}

Note: Mean in the same row with different superscripts differ significantly $(\mathrm{P}<0.05)$; YSSPR= cow's milk probiotic yogurt + roselle; $Y S K P R=$ goat's milk probiotic yogurt + roselle; YSS= cow's milk yogurt; YSK= goat's milk yogurt.

Tabel 8. The concentration of antioxidant and $\mathrm{IC}_{50}$ value from type of yogurt and Vitamin $\mathrm{C}$

\begin{tabular}{|c|c|c|c|c|}
\hline Sample & $\begin{array}{l}\text { Type of yogurt/ } \\
\text { concentration }\end{array}$ & $\begin{array}{c}\text { Average of antioxidant } \\
\text { activity (\%) }\end{array}$ & $\begin{array}{l}\text { Antioxidant concentration } \\
(\mathrm{ppm})\end{array}$ & IC50 (ppm) \\
\hline \multirow[t]{4}{*}{ Type of yogurt } & YSSPR & $84.84 \pm 6.58$ & $25.98 \pm 2.06$ & $9.63 \pm 0.03^{a}$ \\
\hline & YSS & $54.96 \pm 19.75$ & $16.62 \pm 6.19$ & $15.06 \pm 0.18^{\mathrm{b}}$ \\
\hline & YSKPR & $79.66 \pm 14.57$ & $24.36 \pm 4.57$ & $10.27 \pm 0.12^{\mathrm{a}}$ \\
\hline & YSK & $46.29 \pm 11.27$ & $13.91 \pm 3.53$ & $17.99 \pm 0.21^{\mathrm{b}}$ \\
\hline \multirow[t]{4}{*}{ Vitamin C } & 0 ppm & $0.00 \pm 0.01$ & $0.00 \pm 0.00$ & \\
\hline & 5 ppm & $19.23 \pm 0.01$ & $5.43 \pm 0.01$ & $15.07 \pm 0.20$ \\
\hline & $10 \mathrm{ppm}$ & $35.59 \pm 0.01$ & $10.55 \pm 0.01$ & \\
\hline & 20 ppm & $64.52 \pm 0.00$ & $19.62 \pm 0.00$ & \\
\hline
\end{tabular}

Note: Mean in the same column with different superscripts differ significantly $(\mathrm{P}<0.05)$; YSSPR= cow's milk probiotic yogurt + roselle; $Y$ SKPR= goat's milk probiotic yogurt + roselle; YSS= cow's milk yogurt; YSK= goat's milk yogurt.

probiotic yogurt with roselle has the highest with the lowest $\mathrm{pH}$ value. Nutrient composition of goat milk that was used in this research were $87.34 \%$ moisture, $0.8 \%$ ash, $5.22 \%$ fat, $3.9 \%$ protein, and $0.19 \%$ crude fiber based on a wet basis. While, cow's milk had $2.8 \%$ fat and $2.7 \%$ protein based on wet basis. Higher nutrient composition of goat milk than cow's milk caused yield of the fermentation process from lactic acid bacteria on goat's milk produced higher acidity than cow's milk. Beside that, roselle liquid extract also contributed to total titratable acid of yogurt. Roselle liquid extract has high total titratable acid $0.27 \%$.

According to Prayitno (2006), the difference in lactic acid levels is due to the different of lactose contents in different dairy ingredients, thus affecting the lactose breakdown rate and lactic acid synthesis. During 15 days of storage, lactic acid levels tended to decrease. Changes in lactic acid levels during storage were also proportional to the changes in the number of microbes in yogurt. The decreased of the lactic acid level was related to the reduction of lactose as a main source of carbon for the bacteria. This is due to a decrease in the number of LAB cells closely related to a decrease in the $\mathrm{pH}$ of the product due to accumulation of organic acids as metabolites result of fermentation process (Shah, 2009).

The addition of rosella extract also affect the total LAB due to phenolic compounds in roselle extracts. Yogurt with roselle supplementation had lower total lac- tic acid bacteria than yogurt without roselle supplementation. Phenolic compounds of roselle are flavonoids (anthocyanin). Phenol compounds has antibacterial activity by interacting with the bacterial cells through the absorption process involving hydrogen bonding, and disrupted the cytoplasmic membrane so that the metabolism becomes inactive and bacterial growth will be inhibited (Kao et al., 2009). The phytochemical rosella extract also contains saponins and flavonoids. Saponins can act as an antibacterial, by penetrating the cell membranes of the microorganisms, disrupting cell wall and causing cell lysis (Soetan et al., 2006).

The highest total phenolic content was showed by goat's milk probiotic yogurt product supplemented with roselle, and the lowest total phenolic content was showed by goat's milk yogurt product without roselle supplementation. Roselle could increase the total phenolic content in the product. The total phenolic of roselle extract was $66.20 \mu \mathrm{g}$ GAE/mL, with antioxidant activity was $86.86 \%$.

Roselle has antioxidant substances; one of them is anthocyanin pigment. Anthocyanin is a pigment as flavonoid from polyphenol compounds with carbon structure C6C3C6 (Sari et. al., 2015), so that the total phenol of roselle included anthocyanin compounds. Anthocyanins have antioxidant benefits by acting as an electron donor or transferring hydrogen atom to free radicals (Widagdha et. al., 2015). Oxidation reaction can produce free radicals that have unpaired electrons which in turn 
can start chain reactions. Antioxidants prevent chain reactions by removing free radical intermediates and inhibit other oxidation reactions. These unpaired electrons in pairs with the presence of an antioxidant (hydrogen donor / electron) (Valko et al., 2007).

Roselle also contributed to the antioxidant activities of yogurt. The antioxidant mechanism of antioxidant compounds were inhibition and oxidation preventing of fat, so it could protect cells from oxidative damage by free radicals such as singlet oxygen, superoxide, peroxyl radicals, hydroxyl radicals and peroxynitrite. In this research, yoghurt without roselle supplementation had antioxidant activities, although lower than yoghurt with roselle addition. Lactic acid bacteria have high antioxidant activity, which could increase the antioxidant activity in yoghurt and preventing lipid peroxidation. The ability of lactic acid bacteria to break down protein (proteolytic) into small peptides (bioactive peptides) and secondary metabolites from bacterial metabolism (Zhang, 2011).

$\mathrm{IC}_{50}$ is a number that indicates the product concentration (micrograms/milliliter) that is able to inhibit the oxidation process by $50 \%$. The smaller the $\mathrm{IC}_{50}$ value means higher antioxidant activity (Molyneux, 2004). According to the $\mathrm{IC}_{50}$ calculation, four types of yogurt have the $\mathrm{IC}_{50}$ between $9.63-15.06 \mathrm{ppm}$ and $\mathrm{IC}_{50}$ value of vitamin $C$ of 15.07 ppm (Table 8). $\mathrm{IC}_{50}$ of yogurt with roselle addition were lower than yogurt without roselle supplementation.

\section{CONCLUSION}

Roselle extract contributed to quality of goat's milk and cow's milk probiotics yogurt. Cow's milk probiotic yogurt with the supplementation of roselle extract had the highest antioxidant activities. The four types of yogurt were still good to be consumed up to $15 \mathrm{~d}$ at $4^{\circ} \mathrm{C}$ storage.

\section{ACKNOWLEDGEMENT}

This research was partially supported by the Grant for Research and Community Services from DIKTI of the Indonesian Ministry of Education and Culture. The article processing cost also supported by the IBIKK program from DIKTI of the Indonesian Ministry of Education and Culture 2016.

\section{REFERENCES}

Afiyah, D. N., I. I. Arief, \& C. Budiman. 2015. Proteolytic characterization of trimmed beef fermented sausages inoculated by Indonesian probiotics: Lactobacillus plantarum IIA-2C12 and Lactobacillus acidophilus IIA-2B4. Adv. J. Food Sci. Tech. 8: 27-35.

Altgeld, T., R. Gene, G. Glaeske, P. Koli, R. Rosenbrock, \& A. Trojan. 2006. Prevention and Health Promotion. A Program for Improved Health and Social Policy. Bonner Universitaet Sdruckerei, Bonn (DE).

Apostolidis, E., T. I. Kwon, \& K. Shetty. 2006. Potential of cranberry-based herbal synergis for diabetes and hypertension management. Asia Pac. J. Clin. Nutr. 15: 433-441.

AOAC. 2005. Official Methods of Analysis in The Association of
Official Agricultural Chemist. Association of Official Agricultural Chemist. Washington D.C.

Arief, I. I., B. S. L. Jenie, M. Astawan, \& A. B. Witarto. 2010. The effectiveness of probiotic Lactobacillus plantarum 2C12 and Lactobacillus acidophilus 2B4 as antidiarrhea on rats. Med. Pet. 43:137-143. http://dx.doi.org/10.5398/medpet.2010.33.3.137

Arief, I. I., Jakaria, T. Suryati, Z. Wulandari, \& E. Andreas. 2013. Isolation and characterization of plantaricin produced by Lactobacillus plantarum Strains (IIA-1A5, IIA-1B1, IIA-2B2). Med. Pet. 36: 91-100. http://dx.doi.org/10.5398/ medpet.2013.36.2.91

Arief, I. I., Z. Wulandari, E. L. Aditia, M. Baihaqi, Noraimah, \& Hendrawan. 2014. Physicochemical and microbiological properties of fermented lamb sausages using probiotic Lactobacillus plantarum IIA-2C12 as starter culture. Proc. Environ. Sci. 20: 352-356. http://dx.doi.org/10.1016/j.proenv.2014.03.044

Arief, I. I., B. S. L. Jenie, M. Astawan, K. Fujiyama, \& A. B. Witarto. 2015a. Identification and probiotic characteristics of lactic acid bacteria isolated from Indonesian local beef. Asian J. Anim. Sci. 9: 25-36. http://dx.doi.org/10.3923/ ajas.2015.25.36

Arief, I. I., C. Budiman, B. S. L. Jenie, E. Andreas, \& A. Yuneni. 2015b. Plantaricin IIA-1A5 from Lactobacillus plantarum IIA-1A5 forms pores in the membrane of Staphylococcus aureus. Beneficial Microbes. 6: 603-613. http://dx.doi. org/10.3920/BM2014.0064

Astawan, M., T. Wresdiyanti, I. I. Arief, \& D. Febiyanti. 2011. Potency of indigenous probiotic lactic acid bacteria as antidiarrheal agent and immunomodulator. J. Food Technol. Ind. (Indonesia) 22: 11-16.

Astawan, M., T. Wresdiyati, Suliantari, I. I. Arief, \& R. Septiawan. 2012. Production of symbiotic yogurt-like using indigenous lactic acid bacteria as functional food. Med. Pet. 35: 9-14. http://dx.doi.org/10.5398/medpet.2012.35.1.9

BSN. 2009. SNI. 01-2981-2009:Yogurt. Jakarta (ID): Badan Standarisasi Nasional.

Cisse, M., F. Vaillant, A. Kane, O. Ndiayea, \& M. Dornier. 2011. Impact of the extraction procedure on the kinetics of anthocyanin and colour degradation of roselle extracts during storage. J. Sci. Food Agricult. 92:1214-1221. http:// dx.doi.org/10.1002/jsfa.4685

Dalle-Donne, I., R. Rossi, R. Colombo, D. Giustarini, \& A. Milzani. 2006. Biomarkers of oxidative damage in human diseases. Clinical Chem. 52: 601-623. http://dx.doi. org/10.1373/clinchem.2005.061408

Donkor, O. N., A. Henriksson, T. Vasiljevic, \& N. P. Shah. 2006. Effect of acidification on the activity of probiotics in yogurt during cold storage. International Dairy J. 16: 11811189. http://dx.doi.org/10.1016/j.idairyj.2005.10.008

El Sherif, F., S. Khattab, E. Ghoname, N. Salem, \& K. Radwan. 2011. Effect of gamma irradiation on enhancement of some economic traits and molecular changes in Hibiscus sabdariffa L. Life Sci J. 8: 220-229.

[FAO] Food and Agricultural Organization. 2013. Milk and Dairy Products in Human Nutrition. E-ISBN 978-92-5107864-8(pdf). Hal: 41-102. Rome, Italy.

Granato, D., G.F. Branco, A.G. Cruz, A.F.F. Faria, \& N.P. Shah. 2010. Probiotic dairy products as functional foods. Comprehens Reviews in Food Science and Food Safety. 9: 455470. http://dx.doi.org/10.1111/j.1541-4337.2010.00120.x

Kao, E. S., J. D. Hsu, C. J. Wang, S. H. Yang, S. Y. Cheng, \& H. J. Lee. 2009. Polyphenols extracted from Hibiscus sabdariffa L. inhibited lipopolysaccharide-induced inflammation by improving antioxidative conditions and regulating cyclooxygenase-2 expression. Biosci. Biotechnol. Biochem. 73: 385-390. http://dx.doi.org/10.1271/bbb.80639 
Michael, M., R. K. Phebus, \& K. A. Schmidt. 2010. Impact of a plant extract on the viability of Lactobacillus delbrueckii ssp. bulgaricus and Streptococcus thermophilus in non fat yogurt. Int Dairy J. 20: 665-672. http://dx.doi.org/10.1016/j. idairyj.2010.03.005

Molyneux, P. 2004. The use of the stable free radical diphenylpicryl-hydrazyl (DPPH) for estimating antioxidant activity. Songklanakarin J. Sci. Technol. 26: 211-219

Paseephol, T. \& F. Sherkat. 2009. Probiotic stability of yogurt containing Jerusalem artichoke inulins during refrigerated storage. J. Functional Foods 1:311-318. http://dx.doi. org/10.1016/j.jff.2009.07.001

Pelzar, M. J. \& E.C.S. Chan. 2007. Dasar-dasar mikrobiologi Jilid I. Terjemahan Hadioetomo RS, Imas T, Tjitrosomo SS, Angka SL. Indonesia Press, Jakarta.

Prayitno. 2006. Kadar asam laktat dan laktosa yogurt hasil fermentasi menggunakan berbagai rasio jumlah sel bakteri dan persentase starter. Animal Production Journal. 8:131136.

Sari, P., A. Setiawan, \& T. A. Siswoyo. 2015. Stability and antioxidant activity of acylated jambolan (Syzygium cumini) anthocyanins synthesized by lipase-catalyzed transesterification. Int. Food Res. J. 22: 671-676

Shah, N. P. 2009. Probiotic bacteria: Selective enumeration and survival in dairy foods. J. Dairy Sci. 83:894-907. http:// dx.doi.org/10.3168/jds.S0022-0302(00)74953-8

Shetty, K., F. Clydesdale, \& D. Vattem. 2005. Clonal screening and srout based bioprocessing of fenolic phytochemicals for functional foods. Food Biotechnology. CRC Taylor \& Francis, New York. page 603.
Shori, A. B. \& A. S. Baba. 2014. Comparative antioxidant activity, proteolysis and in vitro $\alpha$-amylase and $\alpha$-glucosidase inhibition of Allium sativum-yogurts made from cow and camel milk. J. Saudi Chemic Society 18: 456-463. http:// dx.doi.org/10.1016/j.jscs.2011.09.014

Soetan, K. O., M. A. Oyekunle, O. O. Aiyelaagbe, \& M. A. Fafunso. 2006. Evaluation of the antimicrobial activity of saponins extract of sorghum bicolor L. Moench. Afr. J. Biotech. 5: 2405-2407.

Steel, R. G. D. \& J. H. Torrie. 1995. Principles and procedures of statistica biomedical approach. $3^{\text {rd }}$ edition. McGraw Hill Inc., Singapore.

Szakály, Z., V. Szente, G. Köver, Z. Polereczki, \& O. Szigeti. 2012. The influence of lifestyle on health behavior and preferencefor functional food. Appetite 58: 406-413. http:// dx.doi.org/10.1016/j.appet.2011.11.003

Tsai, P.J., J. Melntosh, P. Pearce, B. Camden, \& B. R. Jordan. 2008. Anthocyanin and antioxidant capacity in roselle (Hibiscus sabdariffa L) extract. FRI. 35:351-356.

Valko, M., D. Leibfritz, J. Moncol, M. T. Cronin, M. Mazur, \& J. Telser. 2007. Free radicals and antioxidants in normal physiological functions and human disease. Int. J. Biochem. Cell Biol. 39: 44-84. http://dx.doi.org/10.1016/j.biocel.2006.07.001

Widagdha, S. 2015. Pengaruh penambahan sari anggur (Vitis vinifera $L$.) dan lama fermentasi terhadap karakteristik fisiko kimia yogurt. Jurnal Pangan dan Agroindustri 3: 248-258.

Zhang, S. 2011. Antioxidative activity of lactic acid bacteria in yogurt. African J. Microbio. Res. 5: 5194-5201. 